\title{
Early Stratification of Sepsis Using Presepsine in Emergency Department (North-East of Romania Experience)
}

\author{
MARAIANA STUPARU CRETU ${ }^{1}$, ANA CAMELIA GRIGORE ${ }^{1}$, ADRIAN MAIER ${ }^{1}$, TUDOR OVIDIU POPA2, \\ ALINA PLESEA CONDRATOVICI ${ }^{1}$, CARMEN DOROBAT ${ }^{2}$, LILIANA LACRAMIOARA PAVEL ${ }^{2 *}$, IOANA BIANCA CHESARU ${ }^{1}$ \\ ${ }^{1}$ Dunarea de Jos University of Galati, Medicine and Pharmacy Faculty, Departament of Dentistry, 47 Domneasca Str., 800008, \\ Galati, Romania \\ ${ }^{2}$ University of Medicine and Pharmacy,Faculty of Generale Medicine, 16 Universitãii Str., 700115, Iasi, Romania
}

\begin{abstract}
Sepsi's syndrome is a common and have devastating implications on health care systems worldwide. Biomarkers may have an importantrole to highlight the presence, absence or severity of sepsis. Retrospective study was conducted on a group of 81 patients with suspected sepsis, presented in the Emergency Department - Emergency County Hospital St. Spiridon lasi during 01.09.2014-30.10.2014. The obtained statistical data's were interpreted using SPSS software and the ROC curve was calculated. The study aims was to establish the following: determining the validity of presepsin as a biological marker in sepsis diagnosis and prognosis; sepsis stratification. The mean age of patients was 64.52 years. Determination of presepsin sensitivity in sepsis early diagnosis was calculated by generating the ROC curve. Following AUC values were found: $A \cup C=0.709$, with a standard error of 0.065 for predicting sepsis; $A U C=0.866$, with a standard error of 0.080 for severe sepsis; $A \cup C=0.864$, with a standard error of 0.053 in the presence of septic shock. The average values of presepsin, related with severity of infection, it was found to be $544.39 \pm 141.93 \mathrm{pg}$./ $\mathrm{mL}$ in case of localized infection; $605.6 \pm 59.55 \mathrm{pg} . / \mathrm{mL}$ in patients with systemic inflammatory response syndrome; $1283.21 \pm 195.74 \mathrm{pg} . / \mathrm{mL}$ in patients diagnosed with sepsis; $4787.8 \pm 1980.43 \mathrm{pg} . / \mathrm{mL}$ in patients presenting severe sepsis and $3734.88 \pm 1732.41 \mathrm{pg} . / \mathrm{mL}$ in patients diagnosed with septic shock. Presepsin level, measured by using quantitative dosage methods, may be helpful in staging patients diagnosed with sepsis and may be used as an indication for initiation of intensive therapy to prevent septic shock. Presepsin level can be used as an early marker of severe prognostic in septic patients.
\end{abstract}

Keywords: emergency department, sepsis, biomarker, presepsin

Sepsis is defined as an infectious disease, evolving as a serious systemic infection and will progress to severe sepsis (acute organ dysfunction caused by an infection or suspected to be caused by an infection) and to septic shock (severe sepsis associated with hypotension that does not respond to fluid resuscitation therapy), installed as a result of delivery in the blood of pathogens, toxins and cellular disintegration products. Sepsis and its clinical forms must be regarded as stages of the same disease [1].

Despite progress in antibiotic therapy, sepsis remains a common and have devastating implications on health care systems worldwide. Estimated average annual cost for care of patients with sepsis was calculated to be worth \$ 16.7 billion in the year 2008 [2].

This pathology is a challenge to overcrowded emergency services. Failure to recognize this entity at the appropriate time, followed by early initiation of therapy and supportive etiological can lead to degradation of vital parameters or even death in these patients. Hence the need for the use of laboratory diagnostic methods easy to use with high sensitivity and specificity to allow an early diagnosis, available in short time in emergency departments (ED).

Biomarkers may have an important role to highlight the presence and severity of sepsis [3-8].

Presepsin (sCD14-ST) - CD 14, is a glycoprotein expressed on the cell membrane surface of monocytes and macrophages present in macrophages, monocytes and granulocytes, is responsible for intracellular signal transmission triggered by the presence of endotoxins. Soluble fraction was called soluble CD14 subtype or presepsin has proved to present increased plasma levels in infections [6-8]
Cut-off value of presepsin, allowing systemic inflammatory response syndrome differentiation within bacterial infectious diseases and nonbacteriene it was found at $600 \mathrm{pg} / \mathrm{mL}$ with a sensitivity of $87.8 \%$ and a specificity of $81.4 \%$ [3].

\section{Experimental part}

Materials and methods

This is a prospective study, conducted on a group of 81 patients which presents clinical signs of infection, out of a total of 10483 patients presented in the Emergency Department - Emergency County Clinical Hospital St. Spiridon lasi, during 01.08.2014-30.10.2014.

The study aims to establish the following:

- Determining the validity of presepsin as biological marker of sepsis diagnosis and prognosis; sepsis stadialization; intrahospital mortality at 28 days after presenting in Emergency Department and admition on clinical wards.

The study protocol included the following group of data: epidemiological, clinical and laboratory variables, elements of therapy administrated when patient is presenting in the Emergency Department - Hospital St. Spiridon - lasi, evolution in 28 days.

\section{Inclusion criteria:}

- Patients over 18 years.

- Patients with clinical signs of infection accompanied by the presence of at least two of the following criteria: temperature $>38^{\circ} \mathrm{C}$ or $<36^{\circ} \mathrm{C}$; heart rate $>90 / \mathrm{min}$; respiratory rate $>20$ / $\mathrm{min}$; leukocytosis $\left(>12,000 \mathrm{~mm}^{3}\right)$ or leukopenia $\left(<4000 \mathrm{~mm}^{3}\right)$. 
Exclusion criteria:

- Patients under 18 years of age

- Pregnant or lactating womans.

The diagnosis of sepsis was made based on the usually clinical signs in conjunction with other investigations, according to the diagnostic criteria of Surviving Sepsis Campaign [4].

For each patient with suspected sepsis in the ED the approach was standardized: clinically evaluation, vital signs were monitored, clinical and laboratory data were recorded in patient case sheets and they received therapeutic measure according to ED diagnosis.

Sepsis was defined as the clinical suspicion of infection together with at least two features of the systemic inflammatory response syndrome (heart rate $>90 \mathrm{bpm}$; respiratory rate $>20 / \mathrm{min}$; temperature $>38.3^{\circ} \mathrm{C}$ or $\angle 36^{\circ} \mathrm{C}$; altered mental status; blood glucose $>140 \mathrm{mg} / \mathrm{dL}$ in a nondiabetic patient; and white cell count $<4000 / \mu \mathrm{L}$ or $>12000 / \mu \mathrm{L}$ ) [4].

Severe sepsis was defined as sepsis with evidence of organ dysfunction (systolic blood pressure $<90 \mathrm{mmHg}$ or mean arterial pressure $<65 \mathrm{mmHg}$; increased $\mathrm{FiO}_{2}$ requirement to keep SpO2> 90\%; urine output $<0.5 \mathrm{~mL}$ / $\mathrm{kg} / \mathrm{h}$; creatinine $>2 \mathrm{mg} / \mathrm{dL}$; bilirubin $>2 \mathrm{mg} / \mathrm{dL}$; platelets $<100000 \mu \mathrm{L}$, international normalized ratio $>1.5$; lactate $>2 \mathrm{mmol} / \mathrm{L}$ ) [4].

Septic shock was defined as severe sepsis plus hypotension despite adequate fluid resuscitation (4).The study was approved by the University of Medicine and Pharmacy Gr.T.Popa lasi ethics committee.Data collected from records meeting inclusion criteria were statistically processed using statistical analysis software SPSS V.22 IBM.

\section{Results and discussions}

Structural in study group there is a slight predominance of females patients (51.85\%). Average age was 64.52 years, with a standard deviation of 15.36 years.

After completion of all clinical investigations and laboratory, 33,33\% from patients were diagnosed with sepsis, including patients with sepsis $17.28 \%$, severe sepsis $6.17 \%$ and septic shock $9.88 \%$, the rest of them having SIRS $58.02 \%$ or localised infection $8.64 \%$.

A percentage of $22.22 \%$ were admited on intensive care unit after evaluation, diagnostics and therapeutics procedures initiated in ED.

The biochemical parameters were determined, needed to support the diagnosis in $E D$, including the $C B C$, from which were used the values of leukocytes, platelets and hemoglobin, $\mathrm{pH}$ and alkaline reserve, lactate, $\mathrm{C}$-reactive protein, urea and creatinine (to monitor renal function), blood glucose determination.

Table 1 describes the characteristics of the patients in terms of clinical and laboratory values, grouped by diagnosis. The table values describe the mean of clinical or laboratory parameters with corresponding standard deviation of each parameter.

The presepsin value were determined for all patients, the average value was $1284.65 \mathrm{pg} / \mathrm{mL}$. The correlations between the presepsin value and presence of sepsis, severe sepsis and septic shock were calculated statistically. The result showed a positive correlation, statistically significant, between presepsin value and subsequent presence of sepsis, severe sepsis and septic shock, a value of 0.439 with a $p=.0001$, meaning a direct link between the two variables.

The ROC curve was drawn, to highlight the correlation between the presepsin values and sepsis in the study group,

Table 1

CLINICAL AND BIOLOGICAL VALUES

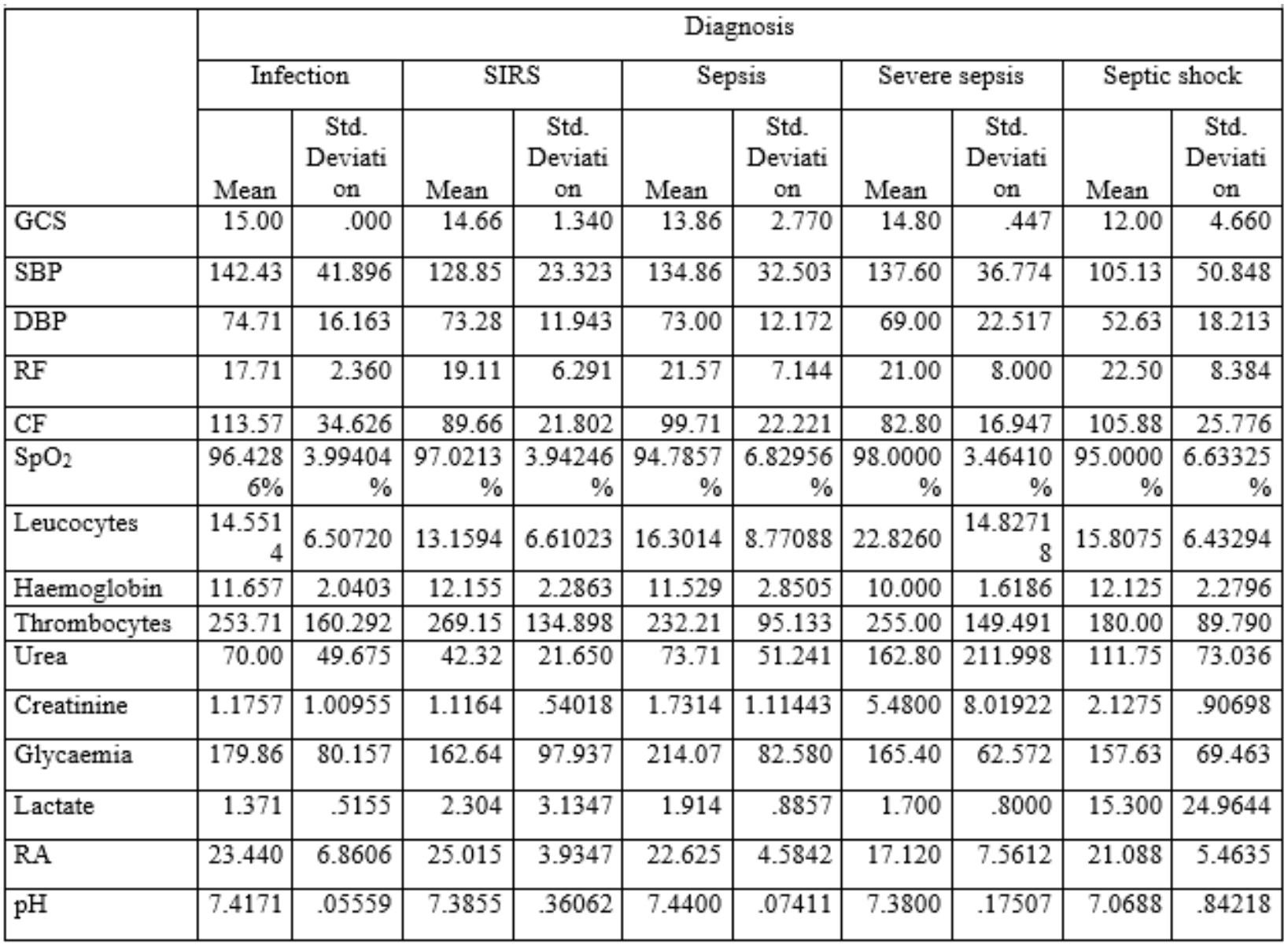




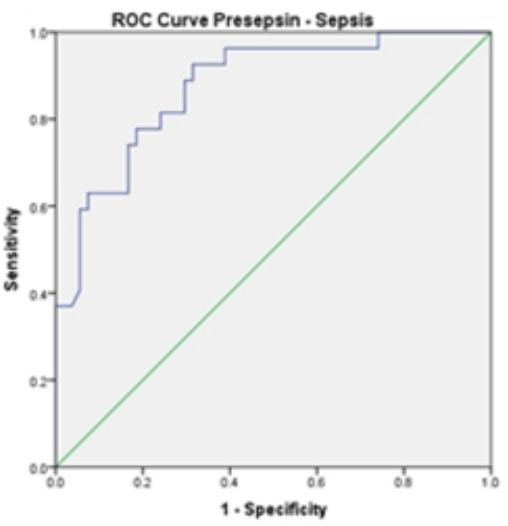

Fig. 1. ROC Curve Presepsin - Sepsis

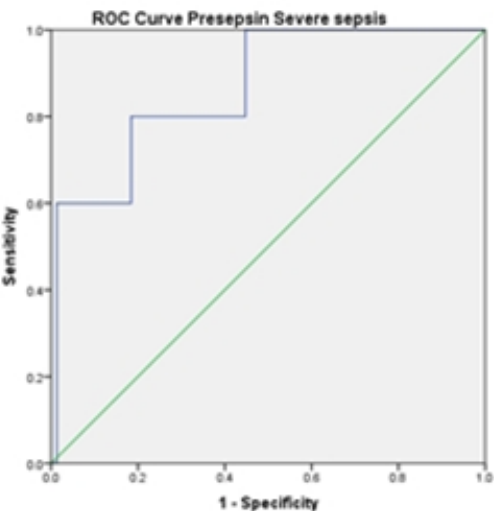

Fig. 2. ROC Curve Presepsin - Severe sepsis

the resulting area under the curve (AUC) had a value of 0.709 with a standard error of 0.065 (fig. 1). After obtaining these values we can say that the probability that a patient from our study to present sepsis is high if presepsin values is higher than $340 \mathrm{pg} / \mathrm{mL}$, within the range of $340 \mathrm{pg} / \mathrm{mL}$ $2724 \mathrm{pg} / \mathrm{mL}$.

We drew also the ROC curve to highlight the relationship between the presepsin values and the presence of severe sepsis, the area under the curve in this case taking a value of 0.866 with a standard error of 0.080 , the predictive power of the likelihood of sepsis where an average presepsin value is $4787.80 \mathrm{pg} / \mathrm{mL}$ is high (fig. 2).

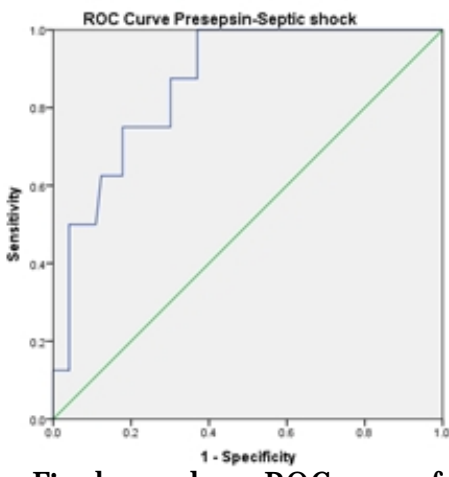

Fig. 3. ROC Curve Presepsin - Septic shock

Finaly we drew ROC curve for presepsin and presence of septic shock, the resulting value of AUC being in this situation of 0.864 , with a standard error of 0.053 , obtaining a high predictive value between the determined value of presepsin and presence of septic shock (fig. 3).

In table 2 are described the average value of presepsin related with severity of infection. The cut-off value calculated from our statistic was $345.5 \mathrm{pg} . / \mathrm{mL}$ in sepsis with sensitivity of $92.9 \%$; 750 pg./mL with sensitivity $80 \%$ in case of severe sepsis and $817.5 \mathrm{pg} . / \mathrm{mL}$ with sensitivity $87.5 \%$ in case of septic shock.

The average age of patients with sepsis, described in the literature, has increased over time, from an average of 64.1 years up to 68.2 years, the average obtained in the present study were of the 64.52 years [5].

Presepsin is described in recent literature as an independent variable that can be associated with the prediction of survival to 28 days and his prognostic accuracy is increased compared with other biomarkers, including procalcitonin [8-10,12-15].

AUC value obtained in our study were 0.709 , with a standard error of 0.065 for the prediction of sepsis in the study lot; $A U C=0.866$ with a standard error of 0.080 in cases of severe sepsis with an average presepsin value of 4787.80 $\mathrm{pg} / \mathrm{mL}$; $A U C=0.864$, with a standard error of 0.053 , again

Table 2

MEAN VALUE PRESEPSIN RELATED WITH SEVERITY OF INFECTION

\begin{tabular}{|c|c|c|c|c|c|}
\hline & \multicolumn{3}{|l|}{ Stadialization } & Statistic & Std. Error \\
\hline \multirow[t]{15}{*}{ Presepsin } & \multirow{3}{*}{$\begin{array}{l}\text { Localized } \\
\text { infection }\end{array}$} & \multicolumn{2}{|l|}{ Mean } & 544.39 & 141.938 \\
\hline & & \multirow{2}{*}{$\begin{array}{l}95 \% \text { Confidence Interval for } \\
\text { Mean }\end{array}$} & Lower Bound & 197.08 & \\
\hline & & & Upper Bound & 891.70 & \\
\hline & \multirow[t]{3}{*}{ SIRS } & \multicolumn{2}{|l|}{ Mean } & 605.60 & 59.556 \\
\hline & & \multirow{2}{*}{$\begin{array}{l}95 \% \text { Confidence Interval for } \\
\text { Mean }\end{array}$} & Lower Bound & 485.72 & \\
\hline & & & Upper Bound & 725.47 & \\
\hline & \multirow[t]{3}{*}{ Sepsis } & \multicolumn{2}{|l|}{ Mean } & 1283.21 & 195.748 \\
\hline & & \multirow{2}{*}{$\begin{array}{l}95 \% \text { Confidence Interval for } \\
\text { Mean }\end{array}$} & Lower Bound & 860.33 & \\
\hline & & & Upper Bound & 1706.10 & \\
\hline & \multirow[t]{3}{*}{ Severe sepsis } & \multicolumn{2}{|l|}{ Mean } & 4787.80 & 1980.439 \\
\hline & & \multirow{2}{*}{$\begin{array}{l}95 \% \text { Confidence Interval for } \\
\text { Mean }\end{array}$} & Lower Bound & -710.78 & \\
\hline & & & Upper Bound & 10286.38 & \\
\hline & \multirow[t]{3}{*}{ Septic shock } & \multicolumn{2}{|l|}{ Mean } & 3734.88 & 1732.419 \\
\hline & & \multirow{2}{*}{$\begin{array}{l}95 \% \text { Confidence Interval for } \\
\text { Mean }\end{array}$} & Lower Bound & -361.65 & \\
\hline & & & Upper Bound & 7831.40 & \\
\hline
\end{tabular}


obtaining a predictive value, positive, between the determined value of presepsin and presence of septic shock. AUC values we obtained are comparable with the values in the few studies published so far, they have published AUC values between 0.640 to 0.790 for predicting the value presepsinemiei sepsis [9.10].

The correlation between the presepsin level and presence of septic shock was recently described in the literature [1]. In our study we found positive correlation, statistically significant, between level of presepsin determined in our study group patients and subsequent presence of sepsis, severe sepsis and septic shock, the calculated value of 0.439 with a $p=0.000$, meaning a direct link between this two variables.

The average values of presepsin, related with severity of infection, obtained in our study were $544.39 \pm 141.93$ $\mathrm{pg} . / \mathrm{mL}$ in case of localized infection; $605.6 \pm 59.55 \mathrm{pg} . /$ $\mathrm{mL}$ in patients with systemic inflammatory response syndrome; $1283.21 \pm 195.74 \mathrm{pg} . / \mathrm{mL}$ in patients diagnosed with sepsis; $4787.8 \pm 1980.43 \mathrm{pg} / \mathrm{mL}$ in patients presenting severe sepsis and $3734.88 \pm 1732.41 \mathrm{pg} . / \mathrm{mL}$ in patients diagnosed with septic shock. In literature we find only a few studies which analyze this correlation, and the result seems to be in the same area of average results. Shozushima et al describe the following average values of presepsin: $294.2 \pm 121.4 \mathrm{pg} / \mathrm{mL}$ in patients without infection; $721.0 \pm 611.3 \mathrm{pg} / \mathrm{mL}$ in patients with local infection; $333.5 \pm 130.6 \mathrm{pg} / \mathrm{mL}$ for systemic inflammatory response sindrome; $817.9 \pm 572.7 \mathrm{pg} / \mathrm{mL}$ in patients diagnosed with sepsis and $1992.9 \pm 1509.2 \mathrm{pg} / \mathrm{mL}$ in patients with severe sepsis [16]. Resulting AUC value in the evaluation of presepsin level as predictive for severe prognostic was 0.764 with a standard error of .062 , a value that allows the statement that in this situation presepsin can help clinician in decision to apply more aggressive therapy from the first moments.

We are aware that our study has some limitation. First limitation is that it is a single-center study, in the major university hospital from North-East of Romania, and we only included patients presenting to ED with sepsis suspicion; direct referrals from other medical specialty and patients developing sepsis in hospital were not included.

\section{Conclusions}

Presepsin, measured by using quantitative dosage method may be helpful in staging patients diagnosed with sepsis and may be used as an indication for early initiation of intensive therapy to prevent installing of septic shock on patients with elevated values.

Presepsin can be useful as an early marker of mortality in septic patients.

\section{References}

1. DOROBT, C., LUCA M. et al: Boli Infecioase: Diagnostic si Tratament Ed. Gr.T.Popa lasi 2012:269-315
2. CIMPOESU D. et al: Protocoale 'i ghiduri actuale în Medicina de Urgenã. Ed. Gr.T.Popa lasi 2011

3. ENDO S, SUZUKI Y, TAKAHASHI G. et all: Usefulness of presepsin in the diagnosis of sepsis in a multicenter prospective study. Journal of infection and chemotherapy. 2012 Dec;18 (6):891-893

4. DELLINGER RP, LEVY MM., RHODES A et al Surviving Sepsis Campaign: International Guidelines for Management of Severe Sepsisand Septic Shock: 2012. Critical Care Medicine 41:580-637

5. GREG S. MARTIN, MD, MSC, DAVID M. MANNINO, MD, MARC MOSS, MD : The Effect of Age on the Development and Outcome of Adult Sepsis. Crit Care Med. 2006;34(1):15-21.

6. ARTERO A., ZARAGOZA R. AND NOGUEIRA J .M.: Epidemiology of Severe Sepsis and Septic Shock, Severe Sepsis and Septic Shock Understanding a Serious Killer, InTech 2012.

7. SHIGETO ODA, MAYUKI AIBIKI, TOSHIAKI IKEDA etal. The J apanese guidelines for the management of sepsis. Journal of Intensive Care 2014, 2:1-38.

8. TAKAHASHI G, SHIBATA S, ISHIKURA $H$ et al. Presepsin in the prognosis of infectious diseases and diagnosis of infectious disseminated intravascular coagulation: A prospective, multicentre, observational study. Eur J Anaesthesiol. 2014; 9;11.

9. ROMUALDO LG, TORRELLA PE, GONZALEZ MV,et al. Diagnostic accuracy of presepsin (soluble CD14 subtype) for prediction of bacteremia in patients with systemic inflammatory response syndrome in the Emergency Department. Clin Biochem. 2014 May;47(78):505-508

10. MASSON S, CAIRONI P, SPANUTH E, et al. Presepsin (soluble CD14 subtype) and procalcitonin levels for mortality prediction in sepsis: data from the Albumin Italian Outcome Sepsis trial. Critical Care 2014;18(1):R6. doi:10.1186/cc13183.

11. CAMILLE CHENEVIER-GOBEAUXA, ELOISE TRABATTONIB, MARIE ROELENS et al. Presepsin (SCD14-ST) in emergency department: The need for adapted threshold values? Elsevier:Clinica Chimica Acta 2014; 427, 34-36

12. GROENEW OUDT M.; ROEST A.; LEIJ TEN F.M.M. etal: Septic patients arriving with emergency medical services: a seriously ill population. European J ournal of Emergency Medicine: 21;5: 330-335 doi: 10.1097/ MEJ. 0000000000000091

13. HICKS C.; ENGINEER R.S.; BENOIT, J.L. et al: Procalcitonin as a biomarker for early sepsis in the emergency department. European J ournal of Emergency Medicine: April 2014 - 21; 2; 112-117; doi: 10.1097/ MEJ .0b013e328361fee2

14. VIALLON A; GUYOMARC'H S.; MARJ OLLET O. Etal: Can emergency physicians identify a high mortality subgroup of patients with sepsis: role of procalcitonin. European Journal of Emergency Medicine. 15(1):26-33, February 2008

15. INNOCENTI F.; BIANCHI S.; GUERRINI E. et al: Prognostic scores for early stratification of septic patients admitted to an emergency department-high dependency unit. European J ournal of Emergency Medicine: 21;4; 254-259 doi: 10.1097/MEJ .0000000000000075

16. SHOZUSHIMA T, TAKAHASHI G, MATSUMOTO N, KOJ IKA M, OKAMURA Y, ENDO S: Usefulness of presepsin (sCD14-ST) measurements as a marker for the diagnosis and severity of sepsis that satisfied diagnostic criteria of systemic inflammatory response syndrome. J Infect Chemother 2011, 17:764-769.

Manuscript received: 18.11 .2016 


\title{
REVISTA DE CHIMIE SI
}

REVISTA MATERIALE PLASTICE POT FI ACCESATE GRATUIT LA URMATOARELE ADRESE:

http://www.revistadechimie.ro/ http://www.revmaterialeplastice.ro/

\section{FREE WEB ACCESS FOR REVISTA DE CHIMIE $A N D$ MATERIALE PLASTICE}

\author{
http://www.revistadechimie.ro/ \\ http://www.revmaterialeplastice.ro/
}

